\title{
Effect of Foreign Direct Investment on Stock Market Performance in USA
}

\author{
Xiqian Wang ${ }^{1, *}$ \\ ${ }^{1}$ University of California, Irvine, California, USA \\ *Corresponding author. Email: xiqianwang1999@gmail.com
}

\begin{abstract}
Stock markets play a critical role in the economy, more so enhancing the economic growth and increasing prosperity of the citizens. The performance of the stock market is influenced by many factors, with foreign direct investment being one of them. Over between 2015 and 2020, FDI (foreign direct investments) fell consistently in the USA, but this was not accompanied by a decline in the stock market performance. In the earlier years, however, the two variables seem to commove. Thus, there is no clear relationship between these two variables. This is the relationship this study sought to find out. The main finding of the paper is that the coefficients of FDI are positive and statistically significant. An increase of FDI by one percent leads to a decrease in stock market index by 0.06 percent.
\end{abstract}

Keywords: Foreign direct investment, Stock market performance, The monopolistic advantage theory, Neoclassical factor mobility theory.

\section{INTRODUCTION}

The importance of efficient capital markets cannot be gainsaid. Well-functioning capital market encourages investments which in turn leads to economic growth and increases the prosperity of the citizens. In addition, the performance of the stock market indicates the current and future health of the economy. One of the factors that affect the functioning of the stock market is foreign direct investments (FDI). There about 5000 stock market indices in the USA. However, the most common are the Dow Jones Industrial Average (DJA), NASDAQ composite index, S\&P 500 and the Wilshire 5000 index. The current study adopts the NASDAQ composite index. The decision to focus on the USA was based on the fact that it is the most developed capital market in the world.

Foreign direct investment, on the other, hand provides alternative sources of capital for a country. It acts as a platform for the promotion of human capital development, create employment, encourage productivity, the flow of technology and improve managerial skills. According to the literature, there exists a positive relationship between FDI and stock market performance, and in turn, the stock market development and financial sector growth positively affect the economy [3]. However, some authors like Johnson argue that FDI has a direct effect on economic growth. Studies on the effect of FDI on stock market development are limited in the USA. The Majority of the existing studies have focused on developing countries like China, India, Pakistan, Latin American countries and Nigeria.

From the trends displayed in "Figure 1", FDI and stock market index show a clear relationship. However, since 2015, the country's FDI has been declining, but the stock market has continued to perform well. Therefore, there is a need to explore this problem, given that there are few papers that have explored this issue in the country. Figure 1 shows the trend in the two variables for the period 1990-2020. 


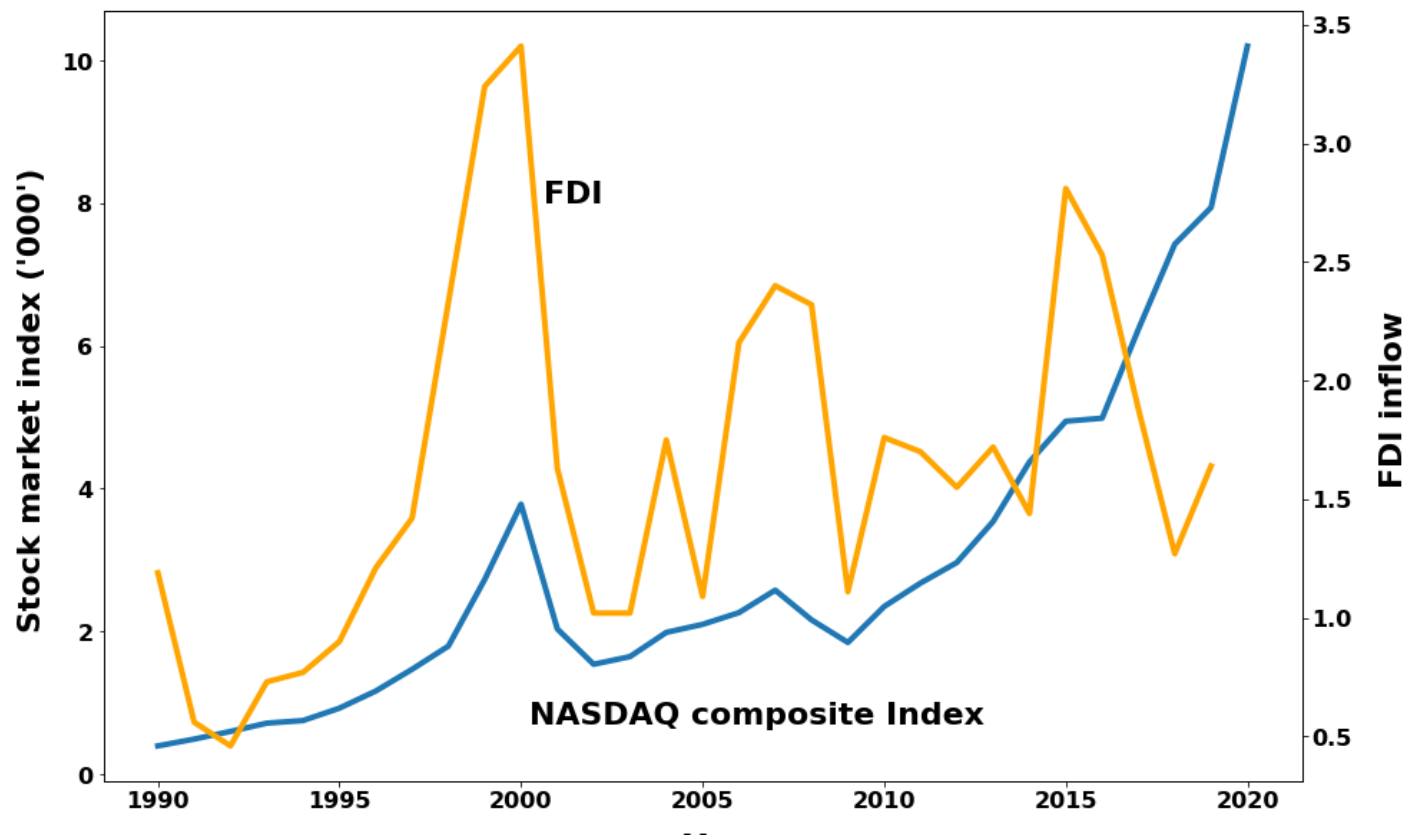

Figure 1 Trends in FDI inflow and stock market performance in USA: 1990-2020.

The "Figure 1" shows that FDI and stock market index are positively related, although their relationship is not clear, more so for the period 2016 to 2020. In this period, the country experienced a reduction in FDI, but the stock market continued to perform well. The figure therefore shows that the two variables are complementary and not substitutes. However, this needs to be explored empirically.

Based on the foregoing discussion, the study will be guided by one research question: What is the effect of FDI on stock market performance in the USA? The study hypothesizes that there exists no relationship between FDI and stock market performance in USA.

In order to answer this objective, this study first undertook the descriptive statistics of the data in order to understand the basic characteristics of the data. A scatter plot was then displayed of various variables with stock market performance. Afterward, the variables were tested for the presence of unit roots, after which the model was estimated using ARDL since some variables were stationary at level, while others were stationary at first difference.

The rest of the paper is organized as follows: Section two gives an overview of the theoretical and empirical literature, Chapter three gives the methodology adopted to answer the study's objectives, Chapter four analyses the data and estimates the model and Chapter five concludes and gives policy recommendations for the study.

\section{LITERATURE REVIEW}

\subsection{The Monopolistic Advantage Theory}

This theory is also known as market imperfection theory. According to this theory, foreign firms face many challenges compared to local firms. These include high operational costs and asymmetry of information. Thus, a foreign firm will only invest in a local economy if it enjoys more advanced technology, higher quality products and economies of scale. However, this theory is limited by the fact that presently, due to the advancement of technology, not many firms are limited by information asymmetry.

\subsection{Neoclassical Factor Mobility Theory}

This theory was developed by Hecksher Ohlins in 1919. It is based on comparative advantage in production and trade. The theory assumes two products, perfectly competitive market, constant returns to scale and zero transaction costs. Different countries have different factor endowments and varying propensity to consume. The theory explains how resources/factors move from the abundant countries to the less abundant ones. Alternatively, it explains how and why FDI flows from one country to another. The theory asserts that surplus factors 
will move from abundant places to scarce locations until factor equalization occurs. The determinants of factor mobility are the real rate of interest, wages and market size. The differing rates of interest also determine how countries distribute resources between consumption and production. A high rate of interest makes countries divert resources from present to future consumption.

\subsection{Eclectic Paradigm (The Ownership, Location and Internalization (OLI)) Theory}

This theory was developed by Dunning in 1977. It combines the oligopolistic and the internalization theories to how FDI flows between countries. The theory explains that for a firm to operate in another country, it must have ownership, locational and internalization advantages. Ownership advantages include tangible and intangible resources (like knowledge, property rights and assets), locational advantages include natural and labor resources and internalization advantages mean that a firm should be able to undertake its own transactions instead of depending on foreign firms. Firms operate abroad if they have these advantages.

\section{EMPIRICAL LITERATURE REVIEW}

Several empirical literatures have been undertaken to find out the effect of foreign direct investment on stock market performance in the world. Some of the studies are reviewed below.

Al Samman and Jamil explored the relationship between stock market development and FDI in six Gulf Cooperation Council (GCC) countries for the period 2002 to 2015 [4]. These countries are Saudi Arabia, Qatar, Bahrain, Kuwait, Oman and UAE. The control variables used in the study are economic growth rate, GDP size, openness and share of domestic credit to private sector. The study used panel unit root tests, cointegration and error correction model. The Error correction model results revealed that FDI does not significantly affect stock market development in the short run. However, it significantly affects stock market performance in the long run.

Rajapakse explored the relationship between the stock market performance and foreign direct investment in Sri Lanka [5]. The study used quarterly data for the period 199Q1 to 2017Q2. The study used a Vector Auto Regression (VAR) model and Granger Causality with two lags after testing for the unit-roots. The results indicated a onedirectional causality from the stock market to the foreign direct investment. In addition, cointegration results established the presence of long-run relationship between stock market performance and FDI.

Kwaku and Wiafe examined the effect of foreign direct investment on stock market development in Ghana by using annual data for the period 1990 to 2010. Other macroeconomic variables used in the study are exchange rate, inflation and GDP per capita growth [7]. The study used Granger causality and cointegration. The study found a positive relationship between the FDI and stock market development. The cointegration results indicated the presence of long run relationship between the two variables. The Granger causality revealed a bi-directional causality between stock market development and FDI. The coefficient of error correction term was -0.18 . This indicates quite a slow adjustment to equilibrium.

Karthik and Kannan (2011) explored the effect of FDI on stock market performance in India [8]. The study used data for the period 1971 to 2006 . The variables used in the study are GNP per capita, inflation and domestic savings as a share of GDP. ARDL bound test was used to test for the presence of long-run relationship while the short-run dynamics were tested using the error correction term. The study found that a positive and strong relationship between the two variables, indicating their complementarity. Cointegration (long-run relationship) was established between stock market performance and the macro variables. The coefficient of the error correction of the error correction term was -0.709 .

Kalim and Shahbaz investigated the effect of FDI on Pakistan's stock market development for the period 1961 to 2006 [2]. The study also explored the role of other macro variables in affecting the stock market performance. Data were obtained from the Pakistan's Economic Survey and the World Bank. The variables used by the authors are market capitalization as a measure of stock market performance, FDI, GNP per capita, domestic savings and inflation. The long run relationship between the variables was explored using the ARDL approach while the short run dynamics were studied using the error correction model. The study found a positive and a statistically significant relationship between the two variables. Other variables that were found to positively affect stock market performance are inflation, savings, income 
per capita and inflation. The short run results revealed that the coefficient of the error correction term (ECT) was negative 0.80 , indicating that 80 percent of all deviations from equilibrium were corrected within a year.

Raza et.al investigated the relationship between and stock market performance in Pakistan for the period 1988-2009 [1]. In addition, the study investigated the role of macroeconomic variables like exchange rate, inflation and savings on stock market performance. The model was estimated using ordinary least squares (OLS). The study found a positive relationship between FDI, the other macroeconomic variables and stock market performance. The coefficients of FDI and savings were positive and statistically significant at a five $S M P=\beta_{1}+\beta_{2} F d i+\beta_{3} G D P P C+\beta_{4} \ln f+$
Where $S M P$ is stock market performance, and was proxied by NASDAQ composite index in this study, $F d i$ is foreign direct investment, $G D P P C$ is GDP per capita, $\ln f$ is inflation, Savings is savings, ${ }^{\text {Open }}$ is openness and Credit private to the private sector by banks.

Descriptive analysis and visualization were conducted before the estimation was done. Afterward, the multicollinearity in the variables was tested. The study then tested for stationarity of the variables using the Augmented Dickey Fuller test. Since some variables were found to be percent significance level. The coefficient of the exchange rate was only statistically significant at ten percent significance level.

\section{METHODOLOGY}

The study used time series secondary data for the period 1990-2020. With the exception of openness data which was obtained from the World Bank Development Indicators, all the other data was obtained from the Federal Bank of St Louis (The data for openness was available at the Federal Bank of St Louis only for the period 1996-2010). The model adopted in this study was derived from the literature review.

The model is presented in equation (1):

\section{$+\beta_{5}$ Savings $+\beta_{4}$ Open $+\beta_{5}$ Credit $+e_{i}$ (1)} stationary at a level while the others were nonstationary, the Autoregressive Distributed Lag Model (ARDL) was used to estimate the model.

\section{DATA ANALYSIS}

This study presents the results for the analysis. The tabulations and the figures in this section are based on author's illustrations.

\subsection{Descriptive Analysis}

Descriptive analysis was conducted to understand the data's characteristics prior to estimation. The results are presented in "Table 1".

Table 1. Descriptive statistics

\begin{tabular}{|l|l|l|l|l|l|l|l|}
\hline & $\begin{array}{l}\text { Credit to private } \\
\text { sector }\end{array}$ & FDI & GDP per capita & Inflation & Openness & Savings & $\begin{array}{l}\text { market } \\
\text { index }\end{array}$ \\
\hline Mean & 50.72 & 1.63 & 47941.69 & 2.45 & 24.25 & 18.33 & 2923.32 \\
\hline Median & 50.55 & 1.59 & 49501.00 & 2.53 & 24.64 & 18.40 & 2161.65 \\
\hline Max & 59.78 & 3.41 & 58112.50 & 5.40 & 30.79 & 21.10 & 10201.51 \\
\hline Min & 44.37 & 0.46 & 36900.00 & -0.36 & 0.00 & 14.00 & 396.24 \\
\hline Std Dev & 3.96 & 0.75 & 6335.73 & 1.13 & 5.63 & 1.61 & 2361.81 \\
\hline Skew & 0.48 & 0.64 & -0.33 & -0.07 & -2.53 & -0.68 & 1.46 \\
\hline Kurt & 2.96 & 2.83 & 1.97 & 4.06 & 12.14 & 3.60 & 4.65 \\
\hline Jarque Bera & 1.16 & 2.07 & 1.94 & 1.43 & 140.89 & 2.84 & 14.61 \\
\hline Prob & 0.56 & 0.36 & 0.38 & 0.49 & 0.00 & 0.24 & 0.00 \\
\hline N & 30 & 30 & 31 & 30 & 31 & 31 & 31 \\
\hline
\end{tabular}

"Table 1" shows that with the exception of the stock market index, most of the other variables have their means close to the median. This indicates that most of the data is normally distributed. 
However, based on Jacque Bera statistic openness and stock market index are not normally distributed. The maximum value of stock market index is very high (10201.65) which was recorded in 2020. To avoid the problems of extreme values, the log of stock market index was used instead. Another notable feature of the data is that the average FDI to USA is very low, with an average value of 1.63 percent, a median of 1.59 percent and a minimum of 0.46 percent and a maximum of 3.41 percent. The minimum value was attained in 1992 while the maximum value was attained in the year 2000. All the standard deviations are less than the mean, indicating the absence of outliers in the data. Next, the study visualized the scatter plot of various variables and stock market performance.

\subsection{Data Visualization}

"Figure 2" plots show the scatter plot of various macroeconomic variables with stock market index in USA.
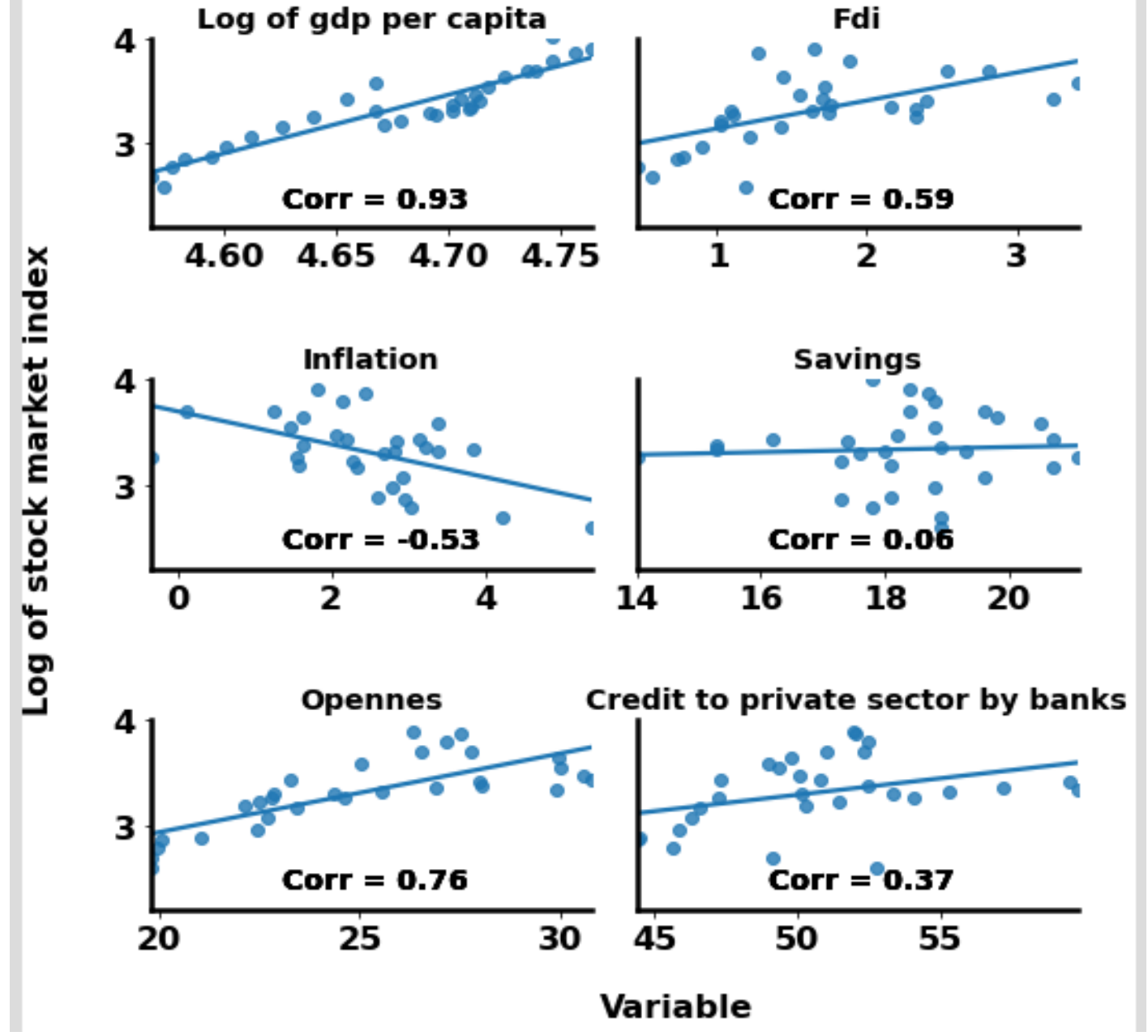

Figure 2 Scatter plot of stok market index with various explanatory variables.

The "Figure 2" shows that there exists a strong positive relationship between the log of GDP, FDI and openness with stock market index. However, stock market index is negatively related to inflation. The ratio of gross domestic savings to GDP and credit to the private sector by banks to GDP exhibits a weak positive correlation. The correlation is strongest between the log of GDP per capita and log of stock market index, and the weakest between savings and the log of stock market index.

\subsection{Multicollinearity Test}

According to Guajarati and Porter, estimation in the presence of multicollinearity leads to large standard errors, wider confidence intervals, insignificant $\mathrm{t}$ ratios and the estimates and their standard errors are sensitive to the changes in the data [11]. Correlations above 0.8 signify the presence of multicollinearity. 
Table 2. Multicollinearity test

\begin{tabular}{|l|l|l|l|l|l|l|}
\hline & $\begin{array}{l}\text { Log of GDP per } \\
\text { capita }\end{array}$ & FDI & inflation & savings & opennes & $\begin{array}{l}\text { Credit to the private } \\
\text { sector by banks }\end{array}$ \\
\hline Log of GDP per capita & 1.00 & & & & & \\
\hline FDI & 0.48 & 1.00 & & & & \\
\hline inflation & -0.49 & -0.20 & 1.00 & & & \\
\hline savings & -0.18 & 0.30 & 0.10 & 1.00 & & \\
\hline Openness & 0.84 & 0.46 & -0.32 & -0.22 & 1.00 & \\
\hline $\begin{array}{l}\text { Credit to the private sector } \\
\text { by banks }\end{array}$ & 0.61 & 0.32 & 0.07 & -0.45 & 0.53 & 1 \\
\hline
\end{tabular}

Since the correlation between openness and log of GDP per capita is very high (in this case 0.84 ), one of the variables had to be dropped. The study dropped openness.

\subsection{Stationarity Test}

According to Enders, time series data exhibit a trend. Estimation in the presence of trending data leads to spurious results [12]. To avoid this problem, the study tested for the presence of unit roots in the data. The study used the Augmented Dickey Fuller method; with the null hypothesis being that the series is non-stationary (has a unit root). The results are presented in "Table 3".

Table 3. Dickey Fuller unit root tests (at levels)

\begin{tabular}{|c|c|c|c|c|}
\hline \multicolumn{5}{|l|}{ Variable } \\
\hline & $\begin{array}{l}\text { No intercept and no } \\
\text { trend }\end{array}$ & Intercept & Trend and Intercept & Conclusion \\
\hline Credit to the private sector & - & $\begin{array}{l}-2.28 \\
(0.18)\end{array}$ & & Stationary \\
\hline \multicolumn{5}{|c|}{$\begin{array}{l}-3.43 \\
(0.02)\end{array}$} \\
\hline Inflation & - & $\begin{array}{l}-4.22 \\
(0.00)\end{array}$ & - & Non-stationary \\
\hline Log of GDP per capita & $\begin{array}{l}4.03 \\
(0.99)\end{array}$ & - & - & Stationary \\
\hline Log of stock market index & - & - & $\begin{array}{l}-2.48 \\
(0.33)\end{array}$ & Stationary \\
\hline Savings & - & $\begin{array}{l}-3.06 \\
(0.04)\end{array}$ & - & Non Stationary \\
\hline
\end{tabular}

Note: The critical values are: $-4.17,-3.51$ and -3.18 using trend and intercept, $-3.58,-2.93$ and -2.60 using intercept only and $-2.61,-1.95$ and -1.61 using no intercept and no trend, at one, five and ten percent significant levels, respectively. The values in brackets are the probabilities.

The results presented in "Table 3" show that three variables (credit to the private sector, log of GDP per capita and log of stock market index) are stationary at level while the other variables are not. Since we have a mix of variables that are stationary while the others are non-stationary at level, the study used the autoregressive distributed lag model (for example see Pesaran, Shin and Smith [14]. This model has several advantages. First, it can be used when the variables are both $\mathrm{I}(0)$ and $\mathrm{I}(1)$ (most 
economic variables have the highest order of integration of (1). Second, the model uses enough lags to be able to capture the underlying dynamics properly. Third, one can study the short and long run dynamics. Fourth, the small sample properties of the model are superior to those of the Johansen cointegration technique and finally (v) the model eliminates residual correlation ad is thus free from endogeneity problem [13].

\subsection{Results}

Having carried the above pre-estimation tests, the study estimated the model presented in equation (3.1) using the ARDL approach. The study chose the maximum number of lags to use as two. However, the optimal lags selected by the model (using Eviews automatic lag selection criteria) are $(1,0,1,2,0,2)$ one lag for stock market index, zero lags for the log of GDP per capita, on lag for the private sector credit, two lags for savings and FDI and zero lags for inflation. "Table 4" presents the results.

Table 4. ARDL regression results

\begin{tabular}{|l|l|l|l|l|}
\hline Variable & Coefficient & Std. Error & t-Statistic & Prob \\
\hline First lag of stock market index & 0.29 & 0.20 & 1.47 & 0.16 \\
\hline Log of GDP per capita & $4.92^{* * *}$ & 1.20 & 4.09 & 0.00 \\
\hline Credit to the private sector & $-0.04^{* * *}$ & 0.01 & -4.75 & 0.00 \\
\hline First lag of Credit to the private sector & $0.02^{* *}$ & 0.01 & 2.54 & 0.02 \\
\hline FDI & $0.06^{* * *}$ & 0.02 & 3.44 & 0.00 \\
\hline First lag of FDI & 0.00 & 0.02 & -0.16 & 0.87 \\
\hline Second lag of FDI & -0.04 & 0.02 & -1.75 & 0.10 \\
\hline Inflation & $0.03^{* *}$ & 0.01 & 2.66 & 0.02 \\
\hline Savings & 0.03 & 0.02 & 1.89 & 0.08 \\
\hline First lag of savings & -0.02 & 0.02 & -1.02 & 0.32 \\
\hline Second lag of savings & 0.03 & 0.01 & 1.93 & 0.07 \\
\hline C & -20.49 & 4.86 & -4.22 & 0.00 \\
\hline
\end{tabular}

The results presented in "Table 4 " show that the coefficients of FDI, the main variable of interest, are positive and statistically significant. An increase of FDI by one percent leads to a decrease in stock market index by 0.06 percent. The findings of this study are not in isolation. These results are in line with Kalim and Shahbaz, Karthik and Kannan, Rajapakse, Kwaku and Wiafe [2][5][7][8]. Coincidentally, none of the papers reviewed found a negative effect of FDI on stock market performance.

The coefficients of the coefficient of $\log$ of GDP per capita, private sector credit and the FDI are statistically significant at one percent level. Thus, an increase in GDP per capita by one percent leads to increase in stock market index by 4.92 percent. Notably, the coefficient of log of GDP per capita is the largest among the other variables. This means that GDP per capita has the strongest influence in USA's capital market. However, the coefficient of first lag of the variable is not statistically significant. Credit to the private sector was found to influence the stock market performance negatively. An increase in private sector credit by one percent leads to a decline in credit to the private sector by 0.04 percent. However, Al Samman and Jamil found the coefficient of credit to the private sector to be positive but statistically insignificant [4].

The coefficient of the second lag of private sector credit and the current value of inflation are statistically significant at a five percent level. An increase in the value of private sector credit one year ago leads to an increase in the present value of stock market index by 0.02 percent. Therefore, while the present value of private sector credit has a negative effect on the performance of stock market in USA, the first lag of the variable has a positive 
effect. Similarly, an increase in inflation by one percent leads to the increase in stock market index by one 0.03 percent.

\section{CONCLUSION}

Since the paper found the coefficient of FDI to be positive and statistically significant, the paper recommends that the USA government should take the necessary measured to encourage FDI inflow, more so given the declining FDI in recent years. These include continued improvement of the ease of doing business like provision of adequate infrastructure and provision of tax incentives. Also, the government should improve economic growth. All these measures will boost the performance of the stock market. Similarly, the government should undertake measures to ensure continued economic growth and increase in GDP per capita as the variables are positively related to stock market performance.

\section{AUTHORS' CONTRIBUTIONS}

This paper is independently completed by Xiqian Wang.

\section{REFERENCES}

[1] Raza, A, Ahmed, Z., Ahmed, M., \& Ahmed, T. (2012). The role of FDI on stock market development: the case of Pakistan. Journal of Economics and Behavioral Studies, 4(1), 2633.

[2] Kalim, R., \& Shahbaz, M. (2009). Impact of foreign direct investment on stock market development: the case of Pakistan. In Global Conference on Business and Economics, ISBN (pp. 978-0).

[3] Rahman, M. M. \& Salahuddin, M. (2009). The determinants of economic growth in Pakistan: Does stock market development play a major role? 38th Australian Conference of Economists (ACE 2009), 28-30 Sept 2009, Adelaide, Australia.

[4] Al Samman, H., \& Jamil, S. A. (2018). The Impact of Foreign Direct Investment (FDI) on Stock Market Development in GCC countries. Pertanika Journal of Social Sciences \& Humanities, 26(3).

[5] Rajapakse, R. P. C. R. (2018). The Relationship between the Stock Market and
Foreign Direct Investment (FDI) in Sri LankaEvidence from VAR and Co-Integration.

[6] Analysis. Global Journal of Management and Business Research: B Economics and Commerce, 18(5).

[7] Kwaku,I. \& Wiafe, A. (2013). FDI and Stock Market Development: Evidence from Ghana. International Journal of Finance and Policy Analysis 5 (1): Spring 2013.

[8] Karthik, R., \& Kannan, D. N. (2011). Impact of foreign direct investment on stock market development: A study with reference to India. International Journal of Management (IJM), 2(2), 75-92.

[9] Kalim, R., \& Shahbaz, M. (2009). Impact of foreign direct investment on stock market development: the case of Pakistan. In Global Conference on Business and Economics, ISBN (pp. 978-0).

[10] Raza, A, Ahmed, Z., Ahmed, M., \& Ahmed, T. (2012). The role of FDI on stock market development: the case of Pakistan. Journal of Economics and Behavioral Studies, 4(1), 2633.

[11] Gujarati, D. N., Porter, D. C., \& Gunasekar, S. (2012). Basic econometrics. Tata McGrawHill Education.

[12] Enders, W. (2008). Applied econometric time series. John Wiley \& Sons.

[13] Hamuda, A. M., Šuliková, V., Gazda, V., \& Horváth, D. (2013). ARDL investment model of Tunisia Theoretical \& Applied Economics, 20(2).

[14] Pesaran, M. H., Shin, Y., \& Smith, R. J. (2001). Bounds testing approaches to the analysis of level relationships. Journal of Applied Econometrics, 16(3), 289-326. http://doi.org/10.1002/jae.616. 